\title{
Journalism for Peace and Justice: Towards a Comparative Analysis of Media Paradigms
}

\author{
ROBERT A. HACKETT \\ School of Communication, Simon Fraser University
}

\begin{abstract}
This paper compares different normative and institutional paradigms of journalism with respect to peaceful conflict resolution and democratic communication. It begins with the problematic but still dominant "regime of objectivity," and then considers three contemporary challengers: peace journalism, alternative media, and media democratization/communication rights movements. The paradigms are compared in terms of such factors as public philosophy, epistemological assumptions, characteristic practices, institutional entailments, relationship to dominant institutions and power structures, allies and opponents, and antagonisms and synergies between them. I conclude with strategic considerations for cultivating social justiceoriented journalism.
\end{abstract}

Struggles for peace and justice are also struggles for democratic communication. That is a core premise of this paper. ${ }^{1}$ Communication practices and institutions (particularly journalism as a culturally central form of storytelling) are interwoven with movements for and against social justice, with contemporary processes of peace and war, $^{2}$ and with other intersecting crises facing humankind-impending climate catastrophe, humanitarian emergencies, terror war, poverty, forced migrations, and human rights abuses (Cottle, 2009, p. 15). Simultaneous with these societal crises, journalism (at least in the North Atlantic heartland of global capitalism) is facing its own crises of legitimacy, institutional identity, and economic viability-crises intensified by both global financial meltdown and the diffusion of digital media.

This paper explores possibilities for transforming journalism so that it might better contribute to more peaceful and democratic social relations. Drawing from secondary literature, I outline and compare four contending paradigms in the media field, each of which mobilizes energy, generates incentives and institutional logics, organizes ways of producing, legitimizing and disseminating knowledge, and reinforces, challenges and/or creates power relations. I start with the arguably disintegrating but still dominant "regime of objectivity" (Hackett \& Zhao, 1998) characteristic of North American journalism's period of "high modernism” (Hallin, 2000). I then outline three challenger paradigms: Peace Journalism, “alternative media” and its correlates, 
and the movement for media democratization and communication rights. ${ }^{3}$ These three paradigms are examples of attempts, respectively, to reform dominant media from within, to bypass dominant media by creating a parallel field, and to reform dominant media from without by changing economic structures and legal contexts. I conclude with brief reflections on how synergies between these paradigms could contribute to progressive change.

While this paper cannot address all of them, the following questions were posed to each paradigm and suggest a much broader research program. What is its normative ideal or public philosophy? What does it propose as the core purpose of journalism? What epistemological assumptions does it make about journalism, and about human capacity to understand social reality? Does this paradigm advance distinct discourses or frames? What specific journalism practices, and institutional arrangements within and beyond the media field, does it entail? What are its historical conditions of existence? Against what problem or "Other" is it reacting? Does the paradigm pose a counter-hegemonic challenge to mainstream journalism or broader power relations? Who are its active promoters, passive constituencies, and likely opponents? What functions or interests does it serve? What antagonisms or synergies exist between these paradigms?

\section{The Regime of Objectivity}

I begin with a paradigm that can be labelled the "regime of objectivity." Dominant in Anglo-American journalism for much of the twentieth century, it is acquiring global significance as journalists seek new roles and institutional supports within formerly authoritarian regimes elsewhere.

Objectivity has positive connotations, such as the pursuit of truth without fear or favour. What objectivity means in practice, however, and whether it is a desirable and achievable goal for reporting in a democratic society, are debatable questions. Objectivity is not a single, fixed "thing." Hackett and Zhao (1998) suggest that in contemporary North American journalism, objectivity constitutes a multifaceted discursive "regime," an interrelated complex of ideas and practices that provide a general model for conceiving, defining, arranging, and evaluating news texts, practices and institutions. They identify five general levels or dimensions in this regime.

First, objectivity comprises goals that journalists should strive for-values concerning journalism's ability to impart information about the world (accuracy, completeness, separation of fact from opinion), and values concerning the stance that reporters should take towards the value-laden meanings of news (detachment, neutrality, impartiality and independence, avoiding partisanship, personal biases, ulterior motives, or outside interests) (McQuail, 1992, chapters 16 \& 17).

Second, such values are assumed to be embodied in a set of newsgathering and presentational practices, discussed below.

Third, this paradigm implies assumptions about knowledge and reality, such as a positivist faith in the possibility of accurate descriptions of the world-as-it-is, through careful observation and disinterested reporting.

Fourth, objectivity is embedded in an institutional framework. It presumes that journalism is conducted by skilled professionals, employed within specialized 
institutions-news organizations, usually corporate-owned, but in which editorial and marketing functions are separated. In their relations with the broader society, journalists and news media are assumed to enjoy legal guarantees of free speech, and independence from the state, political parties, and other outside interests.

Fifth, objectivity provides language for everyday assessments of journalistic performance. This language includes terms like "fairness" and "balance," which some see as more flexible and achievable substitutes for objectivity. Objectivity is often counterposed to propaganda, and personal or partisan "bias."

Who are the beneficiaries of the objectivity regime, and what functions does it serve? Notwithstanding the apparently high-minded altruism and universalism of its ethos - telling truth in the public interest without fear or favour-the historical and sociological roots of journalism objectivity reveal that it serves quite specific interests (Bennett, 2009, pp. 189-192; Hackett \& Zhao, 1998). Non-partisan reporting helped the commercial daily press to displace the party-oriented papers of the nineteenth century, and to aggregate the broadest possible readership for advertisers; the claim to objectivity thus corresponded with the imperatives of mass marketing. Neutral non-partisan language also served the interests of the news agencies that emerged during the 1800s to provide wire copy to newspaper clients with a variety of partisan orientations. To the extent that objective reporting requires specialized skills, it enhances journalists' claim to professional status. The objectivity regime helps to manage the symbiotic relationship between news media and the state. Politicians gain access to media audiences and an opportunity to shape the public definition of political issues; conversely, so long as they follow the rules of objectivity, working journalists gain relatively stable access to senior officials and politicians, without sacrificing their public image of political independence and neutrality. Indeed, the objectivity doctrine "obscured and therefore made more palatable [their] unprofessional compromises with managerial imperatives and corporate politics" (Bagdikian, 1997, p. 180). The claims of objectivity and professionalism also provided ideological cover for media monopolies against the threat of government anti-trust legislation or regulation (McChesney, 2004, pp. 6364). Finally, the practices of objectivity, such as the "balanced" reporting of political issues, opened the public forum to interest groups that had the resources and willingness to play the game (Hackett \& Zhao, 1998, chapter 3). A powerful coincidence of interests underpinned the longevity of the objectivity regime.

In addition to demystifying its social and political roots, academics have repeatedly demonstrated the shortcomings of actually existing journalism when measured against the stated ideal of objectivity, while others have advanced telling critiques of the epistemological foundations of journalism objectivity (see e.g. Hackett \& Zhao, 1998, chapter 5). It is more relevant here, however, to consider the regime's key narrative and reportorial practices and their systematic political consequences. Those practices include "documentary reporting" that allows journalists to transmit only facts that they can observe or that "credible" and authoritative sources have confirmed (Bennett, 2009, p. 193). Journalists also practise "balance" when covering controversies that are regarded as legitimate, providing access to the most dramatic or authoritative leaders of "both sides." Other conventions include the separation of "fact" from "opinion," and the privileging of personalities over structures, political strategies over policy analysis, and discrete and timely events over long-term processes, conditions, or contexts. 
When measured against sensationalism or wilful propaganda, these objectivity practices have much to recommend them (Bagdikian, 1997, p. 179). Yet they also have predictable consequences that are highly problematic for informing public opinion, or incentivizing remedial action, in relation to global crises of conflict, ecology, and poverty. Take the practices of "balance.” In American environmental journalism, "balance" gave undue weight to climate change deniers, resulting in inaccurate reporting at odds with the scientific consensus (Bennett, 2009, pp. 108112). Balance constructs and reduces complex issues to two sides, marginalizing other perspectives, and giving excessive weight either to dramatic and polarizing voices, or to the usual official sources (such as political party leaders). Balance also naturalizes the construction of conflicts as two-sided zero-sum contests, in which one party can only gain at the expense of the other; alternative conflict resolution and win-win options are thus marginalized (Lynch \& McGoldrick, 2005a, pp. 203-212).

Other practices are equally problematic. The reliance on credentialed facts from elite sources, and the privileging of events over contexts both reinforce a global status quo of misery for millions of people, sidelining issues such as poverty, labour exploitation, or private sector corruption that are not on official agendas until they erupt in catastrophic upheavals. Such journalism can contribute to social turbulence as "unestablished groups" adopt disruptive tactics to attract media attention (Bagdikian, 1997, p. 213). Balance and official orientation can also make it difficult for "objective" journalism to challenge governments' war-making policies, even when they are founded on dubious motives and evidence, in the absence of oppositional elite voices. The American media's virtually free pass to the Bush administration as it prepared to invade Iraq in 2003 is now widely recognized as a tragic case in point (DiMaggio, 2009, esp. chapter 3). In a parallel fashion, the journalistic privileging of events and personalities over contexts and structures makes it easier for political leaders to foreground and demonize figures like Saddam Hussein, and to deflect attention from their own motives and contributions vis-à-vis conflict escalation, and from the "collateral damage" of their own policies (such as the massive civilian cost of the pre-2003 sanctions imposed on Iraq).

A related line of critique asserts that the objectivity ethos directly contributes to the production of systematically one-sided or ideological news accounts, and legitimizes media practices that undermine democratic public life, such as a stance of cynical negativism divorced from coherent analytical perspectives, and the framing of politics as a game of insiders motivated only by electoral success (e.g. Bennett, 2009, chapter 6). The appearance of objectivity arguably also masks other media democratic deficits, discussed later, that critical political economists have identified.

Such critiques are contentious, but there is widespread agreement that the objectivity regime is in crisis. Anglo-American journalism is increasingly dissolving within profit-driven conglomerates, its economic basis threatened by audience fragmentation, its occupational ethos shifting from public service (however conservatively defined), to consumerism and commercialism. No single paradigm has replaced objectivity, but several promising challengers have emerged. One of them was pioneered by Johan Galtung, a founder of the discipline of peace and conflict studies (cited in Lynch \& McGoldrick, 2005a, p. 6). Peace Journalism (hereafter $\mathrm{PJ}$ ) is an internal reform movement, operating in the corners of journalism education and news organizations to revise professional practices. 


\section{Peace Journalism}

Like objectivity, PJ is a multi-faceted paradigm. Briefly, as outlined by Lynch and McGoldrick (2005a), PJ is an analytical method for evaluating reportage of conflicts, a set of practices and ethical norms that journalism could employ in order to improve itself, and a rallying call for change. In sum, PJ's public philosophy "is when journalists make choices - of what stories to report and about how to report themthat create opportunities for society at large to consider and value non-violent responses to conflict” (ibid., p. 5).

PJ draws upon the insights of Conflict Analysis to look beyond the overt violence that is the stuff of conventional journalism, which is often tantamount to War Journalism. PJ calls attention to the context of attitudes, behaviour and contradictions, and the need to identify a range of stakeholders broader than the "two sides" engaged in violent confrontation. If War Journalism presents conflict as a tugof-war between two parties in which one side's gain is the other's loss, PJ invites journalists to re-frame conflict as a cat's cradle of relationships between various stakeholders. It also calls on journalists to distinguish between stated demands and underlying needs and objectives, to move beyond a narrow range of official sources to include grassroots voices-particularly victims and peace-builders. PJ seeks to identify and attend to voices working for creative and non-violent solutions, to keep eyes open for ways of transforming and transcending the hardened lines of conflict, and to pay heed to aggression and casualties on all sides, avoiding the conflictescalating trap of emphasizing “our” victims and "their" atrocities. PJ looks beyond the direct physical violence that is the focus of War Journalism, to include the structural and cultural violence (e.g. racism, militarism) that may underlie conflict situations (Hackett, 2006; Hackett \& Schroeder with NewsWatch Canada, 2008, p. 27).

One of PJ's prescriptions is to expand the horizons of conflict reportage, from the immediate conflict arena and the most prominent adversaries, to broader venues and time-frames that multiply the potential causes, instigators, outcomes, and solutions. As one example of PJ's approach, Lynch (2008, chapter 6) analyzed British press coverage of the "Iran nuclear crisis" from this perspective, suggesting that full coverage would (but usually did not) include these topics: the nuclear NonProliferation Treaty; Iran's right to develop civil nuclear power under the NPT's terms; the failure of the UK and US governments to engage in negotiations to disarm their own nuclear arsenal, as obligated under the NPT; any evidence that Iran is not actually developing nuclear weapons; Iran's possible reasons for seeking a nuclear arsenal, if it were to do so, in terms of deterrence against outside threats. ${ }^{4}$

\section{Is PJ Counter-Hegemonic?}

Does PJ constitute a counter-hegemonic challenge to either journalism, or broader social structures? There is no unequivocal answer. While its advocates ask journalists to engage with concepts and ideas from the academic discipline of conflict analysis, they often prefer to speak in the language of journalistic professionalism. Indeed, when initiating PJ as a reform campaign within the journalism field, Lynch preferred to avoid the term "peace journalism," which for 
some may imply an illegitimate prior commitment to extraneous values. He labelled the new initiative "reporting the world" (Lynch, 2002). Indeed, in justifying PJ's prescriptions, Lynch and McGoldrick (2005a, pp. 9, 185, 223, 242) are able to quote from formal editorial guidelines published by one of the world's bastions of the objectivity regime, the $\mathrm{BBC}$, and to use its language-balance, fairness, responsibility (Lynch, 2002, p. 3). One scholar characterizes PJ as a prerequisite of good journalism, one "which only forbids the unacceptable," such as the narrowing of news perspective to that of "war-making elites," or acting as a conduit for propaganda (Kempf, 2007a, p. 4; cited in Lynch, 2008, p. xvi). In this view, PJ embodies the best ideals of journalistic professionalism-including comprehensiveness, context, accuracy, and the representation of the full range of relevant opinions - and it critiques actually existing journalism from that standpoint while providing practical alternatives (Lynch, 2008, p. xviii).

And yet, in some respects, PJ stands between the fields of established media and oppositional social movements. Consider the contrasts between conventional journalism and the peace movement as paradigms for structuring thought and action. The movement values long-term peace-building processes, collective decisionmaking, political commitment, human solidarity, social change, and low-cost grassroots mobilization. Dominant journalism favours timely events, official hierarchies, a stance of detachment, dyadic conflict, a consumerist worldview, and costly production values (Hackett, 1991, pp. 274-275). While PJ should not be equated with the peace movement, it shares some of the above-noted incompatibilities vis-à-vis dominant news discourse.

First, PJ constitutes an epistemological challenge to the objectivity regime. In this view, journalism inherently involves choices; it is a matter of representation, not of reality-reflection. Notwithstanding its professed disinterestedness, conventional "objective" journalism enshrines practices that predictably favour some outcomes and values over others-including, too often, war over peaceful conflict transformation. Objective journalism is thus "irresponsible," in that it shuns Max Weber's "ethic of responsibility" in public affairs - the idea that "one should take into account the foreseeable consequences of one's actions...and adjust one's behaviour accordingly” (Lynch \& McGoldrick, 2005a, p. 218). In conflict situations, far from being passive observers, journalists are often caught in a "feedback loop" with political players. For instance, based on their previous experience of the media, powerful sources create "facts" that they anticipate will be reported and framed in particular ways. Thus, every time journalists re-create those frames, they influence future actions by sources. By focussing on physical violence divorced from context, and on win-lose scenarios, conventional "objective" news unwittingly incentivizes conflict escalation and "crackdowns," impeding a morally and professionally justifiable incentivization of peaceful outcomes (Lynch \& McGoldrick, 2005a, pp. 216-218).

PJ thus challenges the very epistemological basis for a stance of detachment, calling instead for journalists' self-reflexivity vis-à-vis the institutionalized biases of their routine practices, the inescapability of framing and sourcing choices, the nonpassivity of sources, the interventionist nature of journalism, and the potential of its becoming an unwitting accomplice to war propaganda (Lynch, 2008, pp. 10-14). That said, PJ is not renouncing the commitment to truthfulness, only questioning why some kinds of facts and sources are privileged, and how they feed into conflict 
cycles (p. 9). PJ rejects both the positivist stance that journalism simply reports selfevident facts, and the relativist position that "it's all spin," that there is no independent basis to separate truth from propaganda. Instead, PJ offers interdisciplinary intellectual anchorage in peace and conflict studies, pursues the rigour of social science, and is reflexive, explicit about its normative commitments, open to justification, and aware of participant/observer interaction (pp. xv, 21). ${ }^{5}$

Second, beyond epistemological differences, PJ challenges dominant news values, the taken-for-granted and usually implicit criteria that routinely guide journalists in selecting and constructing news narrative. Some PJ scholars suggest otherwise, pointing to specific failures in specific cases, such as the "peace euphoria" framing of the Oslo "peace process" in Israeli media (Mandelzis, 2007). Yet aspects of PJ surely clash with dominant news values. In a recent update of a classic study by Galtung and Ruge (1965), Harcup and O’Neill (2001) identify ten dominant characteristics of newsworthy stories in the British press: power elite, celebrity, entertainment, surprise, bad news, good news (events), magnitude or scope, relevance (to the audience), follow-up (continuity), and the newspaper's own agenda. PJ's emphases on conflict formation and resolution, on win/win positive outcomes, on long-term processes and contexts, and on grassroots sources, challenge the news values of violence, negativity, unambiguity, timeliness, elite nations, and elite people. Indeed, PJ's prescription to broaden the range of sources, to consciously search for the voices and options for peaceful resolution, can be considered a third dimension of its challenge to conventional war reporting.

Some observers see PJ as offering an even more fundamental challenge-not just to the professional conservatism of journalists who cling to "objectivity," and the routinized market share-building formats of profit-oriented news corporations-but also to the entire global war system and its "deadly forms of propaganda," the "lethal synergy of state, corporations, think tanks, and the media (Richard Falk, in Introduction to Lynch, 2008, pp. v, viii).

Other critics fear that PJ challenges a liberal value central to democratic journalism - that of freedom of expression. In the view of Hanitzsch (2004), PJ implies that "bad news" and controversial topics, whose dissemination could contribute to the escalation of conflict, should be avoided. There is no evidence, however, that Peace Journalists actually make such a claim. But in one sense, PJ does challenge the currently hegemonic definition of free speech, as the right of individuals to speak without fear of state punishment. PJ implies not just a right to speak freely, but a right of access by all significant voices to the means of public communication. Free speech needs a chance to be heard, in order to be effective-a normative imperative that underpins alternative media and media democratization movements.

\section{The Environment for PJ}

Given that PJ is, to some extent at least, counter-hegemonic, what are the prospects for actually putting it into practice? What strategies and what enabling environment would help it to flourish?

One broad strategy is to reform the journalism field from within. A landmark review of scholarship on "influences on media content" suggests that there is some 
degree of agency for newsworkers in traditional mass media (Shoemaker \& Reese, 1996). Excellent context-providing documentaries, or news reports on grassroots bridge-building across political divides, can be found within conventional news media. One example is a recent CBC television report on an association of Israeli and Palestinian families who have lost loved ones in the ongoing conflicts. And there is experimental evidence that structural themes and de-escalation-oriented coverage can stimulate audience interest as much as escalation- and elite-oriented War Journalism (Kempf, 2007b).

Still, the barriers to PJ within conventional media are wide-ranging. They include the difficulties of constructing "peace" as a compelling narrative (Fawcett, 2002), the national basis of much of the world's news media and their audiences (notwithstanding the recently hypothesized emergence of "global journalism"), and the embeddedness of dominant media and states in relations of inequality (as the New World Information and Communication Order (NWICO) movement had argued in the 1970s and 1980s) (Hackett, 2006).

Unfortunately, it seems that in the Western corporate media, journalists have neither sufficient incentives, nor autonomy vis-à-vis their employers, to transform the way news is done, without support from powerful external allies. While systematic comparative research is lacking, it seems that PJ is likely to find more fertile ground in societies where media are perceived to have contributed to socially destructive internal conflict or ethnic tensions, and in news organizations which have a stake in avoiding their audiences' dissolution into opposing camps. Moreover, in "transition societies" emerging from authoritarian rule, the political roles and professional norms of journalism may be more open to self-reflexive change than they are in Washington, London, or other imperial citadels of the objectivity regime. ${ }^{6}$ The uptake of PJ in Indonesia, the Philippines and some sub-Saharan African states offers preliminary support for these hypotheses.

PJ's advocates focus on the dominant institutions of public communication, since these are presumably those with the greatest influence on conflict cycles. The current crisis in North American journalism presents opportunities for PJ-there are more footholds in the system for different and experimental forms of journalism. But in light of blockages to $\mathrm{PJ}$ in the dominant media, as well as the growing hybridity and complexity of the global media field, ${ }^{7}$ it is worth exploring other spaces for peacebuilding communication. If indeed PJ is to become "more than an argument at the outer margins of political debate" (Richard Falk, in Introduction to Lynch, 2008, p. ix), it must become part of a broader project. One approach is to build a new field, parallel to currently-existing journalism consisting of alternative organizations and networks, supported by civil society, relatively autonomous vis-à-vis corporate or state power, and capable of putting into practice the ethos of PJ.

\section{Alternative Media}

Compared to PJ, alternative media constitute a less coherent field or paradigm. Debates in the burgeoning scholarly literature reveal its heterogeneity on core questions. How should the phenomenon be demarcated and labeled? Various adjectives have been deployed: alternative, radical, autonomous, independent, tactical, citizens', alternative, participatory, community media (Kidd \& Rodriguez, 
2010, p. 1). Each of these terms, which I use somewhat interchangeably below, has distinct connotations and limitations, reflecting disagreement over other questions: What are "the descriptive features to which we give the greatest priority" for categorizing media and for empirical investigation (Couldry, 2010, p. 25)? Should such media be defined on the basis of their own characteristics, and if so, which?: their content, or their egalitarian, participatory and/or noncommercial processes of production? Or, should they be defined by what they differ from-presumably, the "mainstream", corporate, or state media? And if so, how should such difference be understood? Simply as divergence from a dominant model (perhaps meeting needs unmet by it) or as opposition and resistance to it? If alternative media are oppositional, what is the object of their contestation? The institutionalized forms and concentrated nature of "media power" (Couldry, 2003), or broader forms of social and political domination? And if the latter, if alternative media are contesting political domination, are such political challenges necessarily "progressive," in the broad sense of seeking a more equitable distribution of social, economic, cultural and political resources (Hackett \& Carroll, 2006)? Or can media of the radical right (for example, racist or religious fundamentalist websites) also be considered alternative (Couldry, 2010, p. 25; Downing, Ford, Gil, \& Stein, 2001)?

No attempt is made here to resolve these questions, beyond noting that repressive and exclusionary alternative media are unlikely to constitute communicative spaces for non-violent conflict resolution. For analytical purposes, an ideal type of alternative journalism might include these characteristics: participatory models of production; challenges to established media power (including the professionalization and highly capitalized economy of commercial journalism, and the division between media producers and audiences); more "bottom-up" ways of scanning and reporting the world, challenging conventional elite-oriented and ideologically conservative news values; and a positive orientation to social change, social movements and/or marginalized communities (Hackett \& Zhao, 1998, pp. 206-213; Atton, 2009; Atton \& Hamilton, 2008, p. 1). In light of that description, one can see that alternative journalism is complementary to PJ in several ways.

First, like PJ, alternative journalism represents dissatisfaction with not only mainstream practices or coverage, but also with the epistemology of news (Atton \& Hamilton, 2008, p. 1). By contrast with the objectivity regime, citizens' journalism often valorizes indigenous knowledge, personal testimonials, and participant accounts, over those of professional observers, constructing "a reality that opposes the conventions and representations of mainstream media" (Atton, 2008; Brooten, 2008). Both participatory researchers and practitioners of alternative media embrace "praxis as a method-learning by doing-and as an epistemological point of departure-knowledge starts from the experience (stories) of participants-that encourages critical thinking towards social change” (Riaño-Alcalá, 2006, p. 273; cited in Rodriguez, 2010, p. 137). While alternative journalists are likely more stridently to reject the very possibility or desirability of objectivity, they share with PJ skepticism towards dominant journalism's claims to have achieved it.

Alternative journalism also shares with $\mathrm{PJ}$ a commitment to move beyond the reporting of daily events, to analyze contexts and critically explore structures of power. Moreover, alternative journalism is opposed to poverty, the political exclusion of the poor, and top-down approaches to development (Bekken, 2008; Brooten, 2008; Wilkins, 2008); it resists domination along axes of gender, class, and 
ethnicity, and the under- and mis-representation of subordinate groups. These commitments align well with PJ's call for the voices of victims and peacemakers to be heard, and for structural and cultural violence to be exposed and analyzed.

One example of such alternative journalism is the national magazine Canadian Dimension. Its masthead "For people who want to change the world," is an unabashed rejection of the objectivity regime. By contrast with the corporate press, its decision-making is collective, its financing is readership- rather than advertiserbased, and its editorial content interweaves analysis and reports from a consistently progressive and bottom-up standpoint. Consider coverage of the Toronto G20 summit. While the corporate press focused on a handful of violent protesters and on security costs to taxpayers, Canadian Dimension (issue of September/October 2010) highlighted the mass arrests of protesters and human rights violations by Toronto police, explored the political issues the protesters were raising, and critically analyzed the tactics of various groups associated with the protests.

\section{The Environment for Alternative Journalism}

What about the institutional framework for the practice of alternative journalism? PJ has relatively well-defined institutional locations-journalism education and established news organizations, albeit to date, in the margins. By contrast, alternative journalism is more variegated, hybrid, and complex, spanning the continents and the centuries (see Downing, et al., 2001). Moreover, in a mediascape which is increasingly globalized, digitalized, and networked, and where the producer/user distinction is blurring, it is more difficult to specify the institutional and technological scope of alternative media. Alternative media's contemporary constituencies include "youths, immigrants, minorities, social movements, and cultural and political outsiders" (Bekken, 2008). Its technological and organizational forms include community radio (arguably the most important form globally), internet "radio," small print publications (like the Samizdat underground papers of the Soviet era), weekly urban newspapers, audiocassettes (during the 1979 Iranian revolution), public access television in the US, documentary and eyewitness video for social movements, political and citizens' journalism websites, blogs by unaffiliated individuals, the anti-copyright open source movement...This list is illustrative, far from exhaustive or systematic. Of its various forms, those alternative media that most closely match PJ's ethos are probably those linked to communities seeking to protect themselves from direct violence, or to oppositional social movements seeking the "four Rs" of democratization-recognition, representation, rights, redistribution (Sreberny, 2005) - in the face of structural violence.

Under what conditions is alternative journalism likely to flourish? Alternative media face a paradox: they tend to emerge in periods of upheaval, and in conditions of violence, repression or exclusion, to express needs ignored or actively suppressed by official or commercial media. Political or social repression obviously hinders the production and distribution of alternative media. Yet a supportive political communication regime that lowers the costs of mobilization and enhances alternative media's sustainability (effective guarantees of free speech, recognition and even subsidization by the state) would also reduce the incentives to mobilize. The decline of participatory underground media, as post-communist regimes in eastern and 
central Europe consolidated, offers one historical example (Sparks, 2005). ${ }^{8}$ Quite possibly, the perceived need for PJ arises similarly in situations of crisis, when societies are drifting towards avoidable conflict, or struggling to rebuild and engage in processes of reconciliation.

There are, to be sure, tensions between the two paradigms. First, PJ calls for responsibility and reform within the field of institutionalized journalism. It accepts the presence and desirability of professionalism, and thus the distinction between journalists and citizens/amateurs, with the former privileged in the construction of public discourse. Accordingly, PJ exhibits more concern with the framing of news content (in so far as it feeds into feedback loops and conflict cycles on a broader scale), than with news production processes as such, except for the reform of certain practices such as sourcing.

Alternative and citizens' media, by contrast, prioritize participatory processes, and people telling their own stories. Such media are (by definition) seeking to build a parallel and alternative set of practices and organizations that will often be consciously oppositional to dominant media, and competitive for some of the same resources (audiences, credibility and, occasionally, revenues). Moreover, citizens' media are inherently more precarious than state-owned or market-oriented media. The seeds of PJ may find fertile soil in some corners of the alternative media field, but organizationally, they would need frequent re-planting. And alternative media's typically marginal status means that they often cannot influence the immediate trajectories of conflict cycles.

Second, some alternative media are advocates for one side of a conflict. They may be organs of political contestation, linked to movements that advocate violence or that lack a commitment to universal human rights and/or other-oriented ethics. Within the broad spectrum of ethnic diaspora media, some amplify the most militant or uncompromising views. Such media may see themselves as representing particular communities, but the concept of "community" is politically ambiguous: it can be employed to help construct essentialist and exclusionary identities (Downing, et al., 2001, pp. 39-40). That kind of “community” media may reject PJ's precept of productive dialogue between the different parties in a conflict.

There are nevertheless profound complementarities between PJ and alternative media. They share a commitment to social justice, and to the critical analysis of social structure beyond the quotidian spectacles of conventional news, a commitment implicit in PJ's stance of critical realism, and its call for the exposure and removal of cultural and structural violence. Both paradigms reject the epistemology of the regime of objectivity, insisting that journalists acknowledge they are embedded in social processes and communities, and act ethically on that basis. Both seek to challenge elite war propaganda, and to broaden the range of voices accessed to the public arena, especially those of peacebuilders and the victims of violence in conflict situations. ${ }^{9}$

PJ then, could profitably seek its expansion in alternative and community media. Sometimes community media can have a direct bearing on conflict resolution, as with the abovementioned Colombian radio stations. In especially repressive regimes like Iran's, citizens' underground media may be virtually the only internal communication option for promoting peace and democracy. At the same time, given the limitations of alternative media discussed above, and the need to address the commanding heights of public communication in most conflict situations, another 
paradigm that challenges the concentration of "objective" symbolic power in the media field should also be considered. By intervening in politics and other adjacent fields to change the environment of journalism and the gravitational pulls to which it is subject, movements for media democratization, discussed below, may offer new spaces for public communication favourable to social justice.

\section{Media Democratization and Communication Rights}

Throughout the twentieth century, social movements used communications to mobilize, to gain standing with publics and policymakers, and to pursue political and social change. Implicitly, most movements thereby accepted the media system as an obdurate part of the political environment (Hackett \& Carroll, 2006). Recent decades have added a new dimension, however. Citizens' movements have emerged in a number of countries, demanding democratic reform of media industries and state communication policies, in order to change the media field itself (see e.g. Hackett \& Carroll, 2006; McChesney, 2004; Stein, Kidd and Rodriguez, 2009). Social movement organizations and less formal networks operate both locally (e.g. Media Alliance in San Francisco) and nationally (e.g. the media reform groups Free Press in the US, Campaign for Press and Broadcasting Freedom in the UK, or the citizens' online campaign against restrictive copyright regimes in South Korea (Lee, 2009). In recent years, similar efforts have been directed towards democratizing global media governance, such as CRIS, the Campaign for Communication Rights in the Information Society (Ó Siochrú, 2005). Such groups are not necessarily directly engaged in producing or advocating new models of journalism. Rather, campaigning around a range of issues - intellectual property and the public sphere, broadcast content and regulation, foreign and concentrated media ownership, competition policy, the Internet's accessibility and architecture-they seek to change the structures that currently constrain more diverse and democratic forms of public communication in general.

Thus, the threat against which such movements are mobilizing is the democratic deficit of corporate and state media and telecommunications-a deficit often masked by claims of objectivity and responsiveness to consumers. That deficit has multiple dimensions, including the failure to constitute a democratic public sphere in the face of commercial pressures; the centralization of political and symbolic power; the conversion of economic inequality into unequal media representation and access; the homogenization of discourse, masked by the proliferation of channels and technologies; the loss of localism in many commercial media; the corporate enclosure of knowledge through restrictive user-pay and intellectual property regimes; secretive and elitist communications policy-making; and the erosion of privacy and free expression rights in the post-9/11 climate of surveillance and national security (Hackett \& Carroll, 2006, chapter 1).

Many of these democratic shortcomings are related to the commodification of communication and the global expansion of market relations. Other media deficits derive from state coercion, which, however, is arguably (as with intellectual property regimes) a necessary ingredient of a market-oriented neoliberal order (Hackett \& Carroll, 2006, p. 10). 
Against this democratic deficit of the corporate media and the social order in which they are embedded, what alternative principles do media democrats propose? An analysis of the People's Communication Charter, a landmark document extrapolating from international covenants and circulated by NGOs in the 1990s, suggests these: independence from both government and commercial/corporate control; popular access and participation in communication and policy-making; equality, not just of rights, but of access to the means of communication; diversity and pluralism; human community, solidarity, and responsibility; and universal human rights (Hackett \& Carroll, 2006, chapter 4). A more recent discourse analysis of the Campaign for Communication Rights in the Information Society (CRIS) and other transnational civil society advocacy groups reveals a similar set of principles: freedom, inclusiveness, diversity, participation, and knowledge as a common good (Padovani \& Pavan, 2009).

Each of these principles is multifaceted and susceptible to different and perhaps contradictory emphases. Media diversity, for instance, could refer to types of programming, ideological frameworks, types of ownership, language of service provision, or the representation of various social groups in media content and employment. Moreover, the constituencies promoting media democratization are themselves diverse, ranging from relatively privileged professionals in academic and media institutions, to minorities of colour in the global North, to communities and social movements struggling against authoritarian regimes and/or the impact of neoliberalism in Latin America and elsewhere.

Thus, it is not surprising that the struggle for democratic public spheres is framed differently by different tendencies. At least five such frames can be identified in recent North American media activism (Hackett \& Carroll, 2006, pp. 78-79). A free press, freedom of expression frame invokes mainstream liberal values, but often extends them to include struggle against both corporate and state censorship. Media democratization connotes egalitarian and participatory notions of democracy, as both informed, shared self-government, and participation in the communication system. Media justice, articulated in particular by American activists of colour, emphasizes struggle against broader forms of domination, and links with social justice movements outside the media field (see Arevalo \& Benfield, 2009). A mental or cultural environmental frame implies a struggle against a media-promoted toxic culture, and a parallel with the relatively successful environmentalist movement. Finally, a right to communicate frame links media change with struggles for other human rights, as well as a legalistic focus: the entrenchment of rights recognized in international law, such as Article 19 of the UN Declaration of Human Rights, concerning freedom to seek, receive, and impart information and ideas.

These different frames vary on several dimensions. Some emphasize procedural changes (e.g. communication rights), while others propose substantive moral reform, the redistribution of resources and values (e.g. cultural environmentalism and media justice). Some (free press) emphasize freeing individuals from constraints, while others (media justice) seek to forge new collective identities (Hackett \& Carroll, 2006, p. 81).

Beneath the different frames and forms of mobilization, however, one can identify a coherent paradigm, critical of established media power. It is centered on the institutional organization of public communication so as to enable all segments of society actively to participate in constructing public cultural truth (White, 1995), and 
to be in a position "to introduce ideas, symbols, information and elements of culture into social circulation" so as to reach all other segments of society (Jakubowicz, 1993, p. 41). This paradigm entails the intertwined projects of both democratization of media, and the use of media for broader social change-democratization through the media.

\section{Is Media Democratization Counter-Hegemonic?}

The most radical branches of the movement (such as media justice) are challenging the social order as a whole, seeing media democratization as integral to a larger process of political and social transformation. This tendency has much in common with the alternative media paradigm, rejecting dominant media's claims to a universalizing stance of objectivity, and pointing to the imbrication of media power with an unjust social order.

By contrast, liberals advocate limited reforms with no necessary linkage to broader transformations beyond improving the operation of liberal democracy. Such reforms may be justified in the language of dominant political discourse such as freedom of expression, consumer choice, journalistic professionalism, and indeed the protection of news objectivity.

One approach that has both "mainstream" and oppositional elements is the movement for communication rights. First articulated within UNESCO in 1969 as the "right to communicate," it gained traction during the highly polarized NWICO debates of the 1980s, in the context of the East-West Cold War, and demands from governments of the Non-Aligned Movement for a more "balanced flow" of media content and technology between the global North and South (Padovani \& Nordenstreng, 2005). Hampered by its own internal contradictions and by the bitter opposition of media corporations and neoliberal governments in the West, NWICO was defeated as an inter-governmental movement in the 1980s. But in today's vastly different geopolitical and technological context, the torch for redressing unjust imbalances in communication structures and policies has been picked up by certain academics, NGOs and civil society advocacy networks (like CRIS), and redefined as an effort to implement existing internationally recognized communication rights, in the plural.

On the one hand, this nascent movement speaks the language (widely accepted in principle if not practice) of human rights. On the other hand, it pushes against both the conceptual limitations of those rights, and the institutionalized impediments to their realization. For example, CRIS argues that the conventional liberal conception of freedom of expression is necessary, but too limited, in many ways. It is confined to the level of individuals rather than groups (e.g. cultural, indigenous or linguistic minorities). It emphasizes protecting individuals from censorship or punishment by the state, but is silent about the centralization of means of symbolic production, and other blockages to the effective use of people's right to free expression, such as illiteracy, language barriers, government and corporate secrecy, fear of surveillance, hierarchies of cultural capital (such as the privileging of written documents over oral traditions), or inability to afford schooling (CRIS Campaign, 2005, pp. 19-24).

Communication rights more broadly address the social, cultural, economic, and political environment needed to nurture democratic public communication. If 
democratic communication is a multi-staged cyclical social process of dialogue, "free speech" addresses only part of that cycle: the ability to seek and receive ideas, to generate ideas and opinions, and to express or speak them. Free speech does not guarantee a right to be heard and understood (or the reciprocal obligation to listen and understand), nor does it address the learning/enhancing/creating and responding/sharing stages of the communication process (CRIS Campaign, 2005, pp. 25-26). Conversely, some forms of speech (e.g. manipulative war propaganda, or hate incitement) may not constitute a process of dialogue aiming towards consensus or mutual understanding, and may therefore not merit legal protection as communication (Dakroury, 2009). In the absence of communication rights, conventional legal protection of press and speech freedom may sometimes increase communicative inequalities; for instance, it has yielded judicial support for media corporations seeking to prevent public interest regulation of their power.

\section{Allies and Opponents}

As the NWICO debate demonstrated, the "democratic ideal" in communication has powerful opponents: media conglomerates, authoritarian and/or neoliberal governments, and a "conservative libertarian belief system that is broadcast widely across the globe" (Hamelink, 1995, p. 33), one centered on privatization and the reduction of democratic citizenship to consumer choice within a hierarchical social order. The post-9/11 political climate of fear and "terror war" (Kellner, 2003), the frequently self-marginalizing stance of the Left, and the regime of objectivity that inhibits journalists from joining coalitions, are other obstacles, especially in the US (Hackett \& Carroll, 2006, pp. 131-142).

Notwithstanding such obstacles, social movement organizations for media reform, such as Free Press in the US, have achieved some momentum in the past decade. They have been able, unevenly and not without setbacks, to mobilize constituencies that can be roughly conceptualized as three concentric circles (Hackett \& Carroll, 2006, pp. 51-52). The first comprises groups within and around media industries, whose working life may stimulate awareness of the constraints on creativity and public information rights generated by state and corporate media: media workers, independent producers, librarians and communications researchers. A second circle comprises subordinate or marginalized social groups, whose lack of social, cultural, or economic capital is paralleled by lack of access or misrepresentation in traditional and networked media, and whose interests sometimes bring them into conflict with the social order, particularly social movements that need access to public communication in order to pursue their political project. The outermost circle comprises more diffuse sectors for whom communication policy and practices are rarely a central concern, but who may occasionally mobilize on the media front in order to promote other material or moral interests: parents concerned with media impact on the young, NGOs and small businesses who need affordable access to the internet, communities struggling for local access media or commercial-free public space, citizens concerned with the disconnect between democratic and media agendas, progressive religious or human rights groups advocating ethical conduct and governance. 


\section{Concluding Comments}

What are the strategic implications of the above analysis of journalism paradigms? This is no place for a blueprint, but several themes stand out.

First, the challenger paradigms of peace journalism, alternative media and communication rights stand in an ambivalent relationship to conventional journalism, and to the broader social order of liberal capitalism. I have suggested that in certain respects, they are counter-hegemonic, but they also draw upon such dominant ideals as freedom, democracy, diversity and human rights. In those societies where such norms are well-established ideologically, if less so in practice, it is both principled and strategic to adopt the Habermasian approach of immanent critique, using the system's own legitimating norms to propose institutional reforms. PJ can legitimately present itself as a more complete and accurate form of journalism than the standardized and stunted practices of "objectivity." Movements for media democratization are pursuing communication rights that are formally recognized in national and international law.

While I have noted tensions between the challenger paradigms, they generally share the objectives of expanding the range of media-accessed voices, building an egalitarian public sphere that can raise conflict from the level of violence to that of discussion, promoting the values and practices of sustainable democracy, and offsetting or even counteracting political and economic inequalities found elsewhere (Hackett \& Carroll, 2006, p. 88). ${ }^{10}$ There are also potential strategic synergies between these paradigms. For instance, alternative media help to foreground the democratic deficit of corporate media, and have been key allies in media democratization campaigns, whose success would in turn create more space for PJ, given the ideological and economic entrenchment of War Journalism within existing media structures. As Tehranian (2002, p. 80) notes, "the structure is the message." Media structure influences, if not determines, journalism practices and content. Tehranian identifies the need for more "structural pluralism in media ownership and control" as a precondition for more democratic checks and balances, and for more content pluralism, including the diversity of voices in conflict situations called for by PJ. Structural reforms applicable to all three challenger paradigms include public and community media that offset the biases of corporate and government media towards commercial and political propaganda, subsidies for media production and access in the global South, genuinely internationalist media, and media governance regimes that reinforce popular communication rights. Curran (2002, pp. 239-47) similarly proposes a working model of legal supports and state subsidies for diverse media to serve different democratic purposes_-including social market/minority, civic/interest group and (as the central pillar) public service broadcasting sectors.

Finally, I have critiqued the practices of the objectivity regime, but as a normative ideal, it has democratic dimensions that should be maintained: a commitment to substantive journalism and an ethic of truth-telling on matters of public interest, its capacity to cushion the intrusion of political and commercial interests on news, and its cultivation of ethical, skilled and independent professionalism. As a recent visit to eastern Europe confirmed, these ideals are understandably very attractive to prodemocratic forces in "transition societies" emerging from authoritarian regimes. In North America, traditional journalism has been "hollowed out" by the vectors of hypercommercialism, media mergers, neoliberal deregulation, and corporate 
disinvestment in journalism, bringing to a new climax the longstanding tension between a free press and profit-oriented media industries (McChesney \& Nichols, 2010). In seeking to preserve and reinvigorate the best of the objectivity regime in a cluttered but still corporate-dominated new media ecology, a media democratization movement is already finding allies amongst professional journalists.

For the emerging paradigms to succeed, movements beyond those already engaged in media activism need actively to recognize the democratization of public communication, including journalism, as integral to the success of other social justice struggles.

\section{Notes}

1 I thank Rune Ottosen, Jake Lynch, Ibrahim Shaw and other members of the International Peace Journalism research group for comments and advice, and Angelika Hackett for editorial assistance.

2 Indeed, it can be argued that increasingly "the news media do not only communicate or 'mediate' the events of war; they enter into its very constitution shaping its course and conduct” (Cottle, 2009, p. 109).

3 Potentially, this analysis could be expanded to other paradigms, including anti-war/peace movements, peace and reconciliation processes, and other social change movements.

4 For a visual example, contrasting "War Journalism” and PJ coverage of a suicide bombing in Israel, see Lynch \& McGoldrick, 2005a, pp. 21-26, or their film News from the Holy Land.

5 A critical realist epistemology is evident in PJ's call to distinguish truth from propaganda; to distinguish between stated demands and underlying needs, goals and interests; to look beyond direct physical violence to explore its "invisible" effects (such as cultural militarization or psychological trauma), and the underlying patterns of cultural and structural violence (Lynch \& McGoldrick, 2005a, pp. 28-31; Hackett \& Schroeder with NewsWatch Canada, 2008, p. 44).

${ }^{6}$ I am indebted to Jake Lynch for some of these points; interview, University of Sydney, June 25, 2010.

7 Grassroots Internet-based outlets are introducing new voices and expanding the definition of journalism, but at the same time, dominant media corporations are extending their influence transnationally, through a multi-faceted and uneven process of globalization of media markets, firms, formats, governance and (ambiguously) effects (Zhao \& Hackett, 2005, pp. 6-8).

8 But for a somewhat contrary view, see Bresnahan (2010), who argues that neoliberal media policies, more than changed political conditions, accounted for the decline of Chile's alternative media after Pinochet's downfall.

9 One overlap between PJ and alternative media is provided by the 18 community radio stations in the Magdalena Medio region of Colombia, home of one of the worst internal armed conflicts in the world. The stations' participants may never have heard of PJ, but they have participated in local peace-making processes, mediating between armed factions, cultivating nonviolent conflict resolution in a culture where violence is normalized, and buffering civilians from the negative impact of direct violence. They have done so in “complex, multifaceted, and context-driven” ways (Rodriguez, 2010, p. 143). The stations' mediating role included providing a public forum for discussing, negotiating, and finding common ground between communal groups and bitterly opposed political candidates. Despite her own theoretical preference for the term "citizens'” media, Rodriguez suggests that these community radio stations are "almost" alternative media, in so far as they opened "communication spaces in which communities can consider, experiment with, and witness" alternative, nonviolent ways of dealing with conflict, understanding difference, and developing collective imaginaries (p. 151). The stations' active mediation role, however, distinguishes it from PJ: 
The stations are not sending messages to the community about how to solve conflict in nonviolent ways. Instead, the stations themselves are mediating conflicts; their communication competence is not being used to design messages about peaceful co-existence, but instead the stations are constructing peaceful co-existence through communication. (p. 151; emphasis in original)

10 As an example of shared objectives, PJ has a "democratic prospect" of promoting public deliberation on the question of war. Its critique of conventional war reporting identifies the "missing pieces required to round out the generic war story that stifles democratic praxis; when practised, it elevates public discourse to "a level of complexity and awareness that confounds demonising images” (Ivie, 2009, p. 6). Writing in the wake of the invasion of Iraq, two of the leading exponents of PJ similarly identify its relevance to the liberaldemocratic ideal of free expression that can "animate, and bring about a collision of, alternative views and propositions as to how progress can be made,” a role particularly vital when political elites promote policies as drastic as war (Lynch \& McGoldrick, 2005b, p. 269).

\section{References}

Arevalo, J., \& Benfield, D. M. (2009). You say media, we say justice! The media justice delegation at the world summit on the information society. In L. Stein, D. Kidd \& C. Rodriguez (Eds.), Making our media: Global initiatives toward a democratic public sphere 2, National and global movements for democratic communication (pp. 123-137). Cresskill, NJ: Hampton Press.

Atton, C. (2008). Citizen journalism. In W. Donsbach (Ed.), The international encyclopedia of communication. Malden, MA: Blackwell.

Atton, C. (2009). Alternative and citizen journalism. In K. Wahl-Jorgensen \& T. Hanitzsch (Eds.), The handbook of journalism studies. New York, NY: Routledge.

Atton, C., \& Hamilton, J.F. (2008). Alternative journalism. Los Angeles: Sage.

Bagdikian, B. (1997). The media monopoly. (5 ${ }^{\text {th }}$ ed.). Boston, MA: Beacon Press.

Bennett, W. L. (2009). News: The politics of illusion. ( $8^{\text {th }}$ ed.). New York, NY: Pearson/Longman.

Bekken, J. (2008). Alternative journalism. In W. Donsbach (Ed.), The international encyclopedia of communication. Malden, MA: Blackwell.

Bresnahan, R. (2010). Reclaiming the public sphere in Chile under dictatorship and neoliberal democracy. In C. Rodriguez, D. Kidd \& L. Stein (Eds.), Making our media: Global initiatives toward a democratic public sphere 1, creating new communication spaces (pp. 271-292). Cresskill, NJ: Hampton Press.

Brooten, L. (2008). Grassroots media. In W. Donsbach (Ed.), The international encyclopedia of communication. Malden, MA: Blackwell.

Cottle, S. (2009). Global crisis reporting: Journalism in the global age. Maidenhead, UK: Open University Press/McGraw Hill.

Couldry, N. (2003). Beyond the hall of mirrors? Some theoretical reflections on the global contestation of media power. In N. Couldry \&J. Curran (Eds.), Contesting media power: Alternative media in a networked world (pp. 39-54). Lanham, MD: Rowman \& Littlefield.

Couldry, N. (2010). Introduction to section I. In C. Rodriguez, D. Kidd, \& L. Stein (Eds.), Making our media: Global initiatives toward a democratic public sphere 1, creating new communication spaces (pp. 24-28). Cresskill, NJ: Hampton Press.

CRIS Campaign (2005). Assessing communication rights: A handbook. CRIS.

Curran, J. (2002). Media and power. London and New York: Routledge.

Dakroury, A. (2009). Communication and human rights. Dubuque, IA: Kendall Hunt.

DiMaggio, A. (2009). When media goes to war: Hegemonic discourse, public opinion, and the limits of dissent. New York, NY: Monthly Review Press.

Downing, J. D. H., Ford, T. V., Gil, G., \& Stein, L. (2001). Radical media: Rebellious communication and social movements. Thousand Oaks, CA: Sage.

Fawcett, L. (2002). Why peace journalism isn’t news. Journalism Studies, 3(2), 213-223.

Galtung, J. \& Ruge, M. (1965). The structure of foreign news: The presentation of the Congo, Cuba and Cyprus Crises in four Norwegian newspapers. Journal of International Peace Research 1, 64-91. 
Hackett, R. A. (1991). News and dissent: The press and the politics of peace in Canada. Norwood, NJ: Ablex.

Hackett, R. A. (2006). Is peace journalism possible? In Conflict and Communication Online 5(2) (Fall).

Hackett, R. A., \& Carroll, W. K. (2006). Remaking media: The struggle to democratize public communication. London: Routledge.

Hackett, R. A., Schroeder, B. \& NewsWatch Canada. (2008). Does anybody practice peace journalism? A cross-national comparison of press coverage of the Afghanistan and Israeli-Hezbollah Wars. Peace \& Policy, 13, 8-25.

Hackett, R.A., \& Zhao, Y. (1998). Sustaining democracy? Journalism and the politics of objectivity. Toronto: Garamond [now University of Toronto Press].

Hallin, D.C. (2000). Commercialism and professionalism in the American news media. In J. Curran \& M. Gurevitch (Eds.), Mass Media and Society ( $3^{\text {rd }}$ ed.) (pp. 218-237). London: Arnold.

Hamelink, C. (1995). The democratic ideal and its enemies. In P. Lee (Ed.), The democratization of communication (pp. 15-37). Cardiff: University of Wales Press.

Hanitzsch, T. (2004). The peace journalism problem: Failure of news people—or failure on analysis? In T. Hanitzsch, M. Loffelholz \& R. Mustamu (Eds.), Agents of peace: Public communication and conflict resolution in an Asian setting (pp. 185-209). Jakarta: Friedrich Ebert Stiftung.

Harcup, T., \& O’Neill, D. (2001). What is news? Galtung and Ruge revisited. Journalism Studies, 2(2), 261-80.

Ivie, R.L. (2009). Breaking the spell of war: Peace journalism's democratic prospect. Javnost-The Public, 16(4), 5-22.

Jakubowicz, K. (1993). Stuck in a groove: Why the 1960s approach to communication democratization will no longer do. In S. Splichal \& J. Wasko (Eds.), Communication and democracy (pp. 33-54). Norwood: Ablex.

Kellner, D. (2003). From 9/11 to terror war: The dangers of the Bush legacy. Lanham, MD: Rowman \& Littlefield.

Kempf, W. (2007a). Peace journalism: A tightrope walk between advocacy journalism and constructive conflict coverage. Conflict and Communication Online, 6(2).

Kempf, W. (2007b). Two experiments focusing on de-escalation oriented coverage of post-war conflicts. In D. Shinar \& W. Kempf (Eds.), Peace journalism: The state of the art (pp. 136-157). Berlin: Verlag Irena Regener.

Kidd, D., \& Rodriguez, C. (2010). Volume introduction. In C. Rodriguez, D. Kidd \& L. Stein (Eds.), Making our media: Global initiatives toward a democratic public sphere 1, Creating new communication Spaces (pp. 1-24). Cresskill, NJ: Hampton Press.

Lee, K. (2009). The electronic fabric of resistance: A constructive network of online users and activists challenging a rigid copyright regime. In L. Stein, D. Kidd \& C. Rodriguez (Eds.), Making our media: Global initiatives toward a democratic public sphere 2, National and global movements for democratic communication (pp. 189-206). Cresskill, NJ: Hampton Press.

Lynch, J. (2002). Reporting the world. Taplow Court, UK: Conflict \& Peace Forums.

Lynch, J. (2008). Debates in peace journalism. Sydney: Sydney University Press.

Lynch, J., \& McGoldrick, A. (2005a). Peace journalism. Stroud, UK: Hawthorn.

Lynch, J., \& McGoldrick, A. (2005b). Peace journalism: A global dialogue for democracy and democratic media. In R.A. Hackett \& Y. Zhao (Eds.), Democratizing global media: One world, many struggles (pp. 269-288). Lanham, MD: Rowman and Littlefield.

Mandelzis, L. (2007). Representations of peace in news discourse: Viewpoint and opportunity for peace journalism. In D. Shinar \& W. Kempf (Eds.), Peace journalism: The state of the art (pp. 97-110). Berlin: Verlag Irena Regener.

McChesney, R. (2004). The problem of the media. New York, NY: Monthly Review Press.

McChesney, R., \& Nichols, J. (2010). The death and life of American journalism. Philadelphia: Nation Books/Perseus.

McQuail, D. (1992). Media performance: Mass communication and the public interest, London, Newbury Park, New Delhi: Sage.

Ó Siochrú, S. (2005). Finding a frame: Towards a transnational advocacy campaign to democratize communication. In R. A. Hackett \& Y. Zhao (Eds.) Democratizing global media: One world, many struggles (pp. 223-242). Lanham, MD: Rowman \& Littlefield.

Padovani, C. \& Nordenstreng, K. (2005). From NWICO to WSIS: Another world information and communication order? Introduction. Global Media and Communication, 1, 264 . At http://gmc.sagepub.com/content/1/3/264. 


\section{Robert A. Hackett}

Padovani, C., \& Pavan, E. (2009). The emerging global movement on communication rights: A new stakeholder in global communication governance? In L. Stein, D. Kidd \& C. Rodriguez (Eds.), Making our media: Global initiatives toward a democratic public sphere 2, National global movements for democratic communication (pp. 223-242). Cresskill, NJ: Hampton Press.

Riaño-Alcalá, P. (2006). Dwellers of memory: Youth and violence in Medellin, Colombia. New Brunswick, NJ: Transaction.

Rodriguez, C. (2010). Knowledges in dialogue: A participatory evaluation of citizens' radio stations in Magdalena Medio, Colombia. In C. Rodriguez, D. Kidd \& L. Stein (Eds.), Making our media: Global initiatives toward a democratic public sphere 1, Creating new communication spaces (pp. 131-154). Cresskill, NJ: Hampton Press.

Shoemaker, P., \& Reese, S. (1996). Mediating the message: Theories of influences on mass media content ( $2^{\text {nd }}$ ed.). White Plains, NY: Longman.

Sparks, C. (2005). Civil society as contested concept: Media and political transformation in eastern and central Europe. In R.A. Hackett \& Y. Zhao (Eds.), Democratizing global media: One world, many struggles (pp. 37-56). Lanham, MD: Rowman \& Littlefield.

Sreberny, A. (2005). Globalization, communication, democratization: Toward gender equality. In R.A. Hackett \& Y. Zhao (Eds.), Democratizing global media: One world, many struggles (pp. 256-267). Lanham, MD: Rowman \& Littlefield.

Stein, L., Kidd, D., \& Rodriguez, C. (2009). Making our media: Global initiatives toward a democratic public sphere 2, National and global movements for democratic communication. Cresskill, NJ: Hampton.

Tehranian, M. (2002, April). Peace journalism: Negotiating global media ethics. Harvard Journal of Press/Politics, 7(2).

White, R. A. (1995). Democratization of communication as a social movement process. In P. Lee (Ed.), The democratization of communication (pp. 92-113). Cardiff: University of Wales Press.

Wilkins, K. G. (2008). Development communication. In W. Donsbach (Ed.), The international encyclopedia of communication. Malden, MA: Blackwell.

Zhao, Y., \& Hackett, R.A. (2005). Media globalization, media democratization: Challenges, issues, and paradoxes. In R.A. Hackett \& Y. Zhao (Eds.), Democratizing global media (pp. 1-33). Lanham, MD: Rowman \& Littlefield. 